\title{
Xiao-Ai-Ping inhibits proliferation and induces apoptosis of chronic myeloid leukemia cells through downregulating $\beta$-catenin signaling pathway
}

\author{
Tongtong Wang ${ }^{2, *}$, Jing Du ${ }^{3, *}$, Bingyu Chen ${ }^{1}$, Wei Zhang ${ }^{4}$, Zhen Wang ${ }^{1}$, Ke Hao ${ }^{1}$, \\ Xin Wang ${ }^{2}$, Yi Zhou ${ }^{2}$, Qiaojuan Zhu ${ }^{2}$, Xiangmin Tong ${ }^{2}$ and Ying Wang ${ }^{1,2}$ \\ ${ }^{1}$ Department of Blood Transfusion, Zhejiang Provincial People's Hospital, People's Hospital of Hangzhou Medical College, \\ Hangzhou, Zhejiang 310014, China \\ ${ }^{2}$ Clinical Research Institute, Zhejiang Provincial People's Hospital, People's Hospital of Hangzhou Medical College, Hangzhou, \\ Zhejiang 310014, China \\ ${ }^{3}$ Department of Laboratory Medicine, Zhejiang Provincial People's Hospital, People's Hospital of Hangzhou Medical College, \\ Hangzhou, Zhejiang 310014, China \\ ${ }^{4}$ Department of Hepatopancreatobiliary Surgery, Zhejiang Provincial People's Hospital, People's Hospital of Hangzhou Medical \\ College, Hangzhou, Zhejiang 310014, China \\ "These authors contributed equally to this work
}

Correspondence to: Ying Wang, email: nancywangying@163.com

Xiangmin Tong, email: tongxiangmin11@163.com

Keywords: Xiao-Ai-Ping; chronic myeloid leukemia; proliferation; apoptosis; $\beta$-catenin

Received: August 08, $2017 \quad$ Accepted: November 16, $2017 \quad$ Published: January 04,2018

Copyright: Wang et al. This is an open-access article distributed under the terms of the Creative Commons Attribution License 3.0 (CC BY 3.0), which permits unrestricted use, distribution, and reproduction in any medium, provided the original author and source are credited.

\section{ABSTRACT}

The active ingredients of Xiao-Ai-Ping (XAP) injection are Marsdeniae tenacissimae extraction, which is a traditional Chinese herb has been used to treat multiple diseases for a long time. However, the possible roles and mechanisms of XAP in chronic myeloid leukemia (CML) still remain unknown. In this study, we examined the effects of XAP on proliferation and apoptosis of $\mathrm{K} 562$ cells (CML cell line) and peripheral blood mononuclear cell (PBMCs) from CML patients. Here, we found that XAP could inhibit the proliferation of K562 cells and induce the apoptosis of $\mathrm{K562}$ cells via mitochondrial pathway. In addition, XAP inhibited the migration of K562 cells through downregulating the expression levels of chemokine SDF-1 and its receptor CXCR-4. In addition, XAP down-regulated $\beta$-catenin and CyclinD1 level, and up-regulated GSK3 $\beta$ level in K562 cells. Interestingly, over-expression of $\beta$-catenin restored the XAP-induced apoptosis of K562 cells. Furthermore, XAP significantly inhibited the proliferation and induced the apoptosis of PBMCs from CML patients, compared with healthy people. In conclusion, XAP could inhibit the proliferation and migration of CML cells, and induce the apoptosis of CML cells through down-regulation of $\beta$-catenin and SDF1/CXCR-4 signaling.

\section{INTRODUCTION}

Chronic myeloid leukemia (CML) is characterized by the expansion of morphologically abnormal and malignant uncontrolled accumulation of hematopoietic stem cells that arises from $\mathrm{t}(9: 22)$ (q34:q11) reciprocal translocation, forming the Philadelphia $(\mathrm{Ph})$ chromosome. $B C R-A B L$ fusion protein, encoded by $\mathrm{Ph}$ chromosome, has constitutively tyrosine kinase activity, resulting in leukemogenesis [1-6]. Various signaling pathways were activated by the $B C R-A B L$ oncoprotein, such as phosphoinositide 3-kinase (PI3K) pathway, the rat sarcoma (Ras) and extracellular signal-regulated kinase (ERK) pathway, which promote the proliferation of cells, inhibit the apoptosis and change cell adhesion [7-9]. BCR$A B L$ fusion protein plays a critical role in the pathogenesis of CML, certainly the therapy of CML is focusing on the specific protein inhibitors [10] such as imatinib mesylate (IM), which has become the standard therapy in CML, practically all patients received IM therapy when first 
diagnosed CML [11]. Despite standard-dose imatinib achieved remarkable results, still one third of patients do not have an acceptable prognosis [11]. And a large number of patients were resistant to IM therapy and relapsed, due to the point mutations in the kinase domain of $B C R-A B L$ enzyme $[12,13]$. Also if patients are in the progressive stage of CML, it is even more likely to be IM resistant [14]. The second generation of tyrosine kinase inhibitors (TKIs), including nilotinib, dasatinib, bosutinib, and ponatinib, still did not achieve ideal therapeutic efficacy [15-17]. Additionally, only $15 \%$ CML patients got transplantation due to various reasons [18]. Therefore new antitumor drugs or compounds are deeply needed to improve the therapeutic efficacy of CML.

In the past years, dissimilar treatment protocols have been attempted to ameliorate the treatment status, suppressing the proliferation, promoting apoptosis, leading to cell cycle arrest, inducing differentiation by compounds or natural products $[19,20]$. At present, more than half of the antitumor drugs come from natural plants directly or indirectly [21]. Chinese medicines have been widely used in the field of cancer treatment with less side effects and low costs [22]. Xiao-Ai-Ping (XAP) injection is extracted from Marsdenia tenacissima, which is a traditional Chinese medicine, the Asclepiadaceous plant Marsdenia tenacissima (Roxb.)'s dried stems. Wight et Arn. Pharmacology studies have revealed that Marsdenia tenacissima and its derivatives induced hematologic neoplasm cells apoptosis [23]. However the effective pharmacological ingredients and associated mechanisms have not been clarified.

In this study, we examined the efficacy and mechanism of XAP on CML cell line. The results showed that XAP inhibited proliferation, induced apoptosis and inhibited migration on K562 cells and peripheral blood mononuclear cell (PBMCs) from CML patients, compared with control groups. Further we found that $\mathrm{Wnt} / \beta$-catenin signaling pathway played a key role in XAP's function on K562 cells. These findings indicate the potential therapeutic efficacy of XAP on CML through down-regulation of $\beta$-catenin and SDF1/CXCR4 signaling.

\section{RESULTS}

\section{$\mathrm{XAP}$ reduced the viability and promoted the apoptosis of $\mathrm{K562}$ cells}

To investigate the effects of XAP on growth of CML cells, we firstly performed CCK 8 assays by using K562 cells (CML cell line). Cultured K562 cells were incubated for $24 \mathrm{~h}$ with increasing concentrations (from 0 to $256 \mu \mathrm{l} /$ $\mathrm{ml}$ ) of XAP. Cell viability (relative to control) and IC50 were measured by CCK-8 assays. As shown in Figure 1A, XAP significantly reduced the cell viability of K562 cells in a dose-dependent manner. IC50 value of XAP for $24 \mathrm{~h}$ of $\mathrm{K} 562$ cells was $31.77 \mu \mathrm{l} / \mathrm{ml}$. XAP also inhibited the cell viability of K562 cells in a time-dependent manner (for 24 $\mathrm{h}, 48 \mathrm{~h}$ and $72 \mathrm{~h}$ ) (Figure 1B). These results suggest that XAP could reduce the viability of K562 cells both in dose and time-dependent manners.

To further examine whether XAP affect the cell survival of K562 cells, we performed the flow cytometry assays. K562 cells were treated with $0-24 \mu \mathrm{l} / \mathrm{ml}$ XAP for $24 \mathrm{~h}$, and then cells were stained with Annexin V and propidium iodide (PI) and analyzed by flow cytometry assays. As shown in Figure 1C-1G, different stages of cell death were distinguished: normal cells (Annexin $\mathrm{V}^{-} / \mathrm{PI}^{-}$), early apoptotic cells (Annexin $\left.\mathrm{V}^{+} / \mathrm{PI}^{-}\right)$, late apoptotic cells (Annexin $\mathrm{V}^{-} / \mathrm{PI}^{+}$), and cell debris $\left(\right.$Annexin $\left.\mathrm{V}^{+} / \mathrm{PI}^{+}\right)$. XAP treatment significantly increased the number of apoptotic cells (early apoptotic cells plus late apoptotic cells) in a dose-dependent manner (Figure 1C-1G). The quantitative analysis revealed that the percentage of apoptotic cells was $4.29 \pm 1.48,10.93 \pm 1.95,21.64 \pm 2.05,42.61 \pm 1.38,54.69$ \pm 3.85 , when treated with, $0 \mu \mathrm{l} / \mathrm{ml}, 6 \mu \mathrm{l} / \mathrm{ml}, 12 \mu \mathrm{l} / \mathrm{ml}, 24$ $\mu \mathrm{l} / \mathrm{ml}$ and $48 \mu \mathrm{l} / \mathrm{ml}$ of XAP, respectively (Figure $1 \mathrm{H}$ ) .

To further confirm the increase of apoptosis of K562 cells induced by XAP, the expression level of apoptosis proteins was detected by western blot after XAP treatment. As shown in Figure 2A, 2C-2E, the pro-apoptotic protein Bax, c-PARP and c-Caspase-3 were significantly upregulated in a dose-dependent manner, whereas, the expression levels of inhibiting apoptosis protein $\mathrm{Bcl}-2$ was significantly down-regulated by XAP treatment, compared with control group (Figure 2B, 2F). To further study the mechanism of apoptosis induced by XAP, western blot was conducted to detected the expression of mitochondria associated proteins. The results showed that the expression of Ndufs1, CLPP, COXIV were both down-regulated significantly (Figure 2C-2E, Supplementary Figure 1A), while the c-Caspase-9 expression level was up-regulated obviously (Supplementary Figure 1A, 1B). These results suggest that XAP could induce the apoptosis of K562 cells via the mitochondrial pathway.

\section{XAP inhibited the migration of $\mathrm{K562}$ cells through downregulating the expression levels of chemokine SDF-1 and its receptor CXCR-4}

To further test the effects of XAP on the migration of K562 cells, transwell chamber migration assays were performed. In this assay, K562 cells were allowed to migrate for $12 \mathrm{~h}$ in the presence or absence of XAP in the lower chamber. As shown in Figure 3A-3D, with the concentrations of XAP increasing, the number of K562 cells migrating through the transwell chamber was significantly decreased (Figure 3E). The chemokine SDF1 and its receptor CXCR-4 contribute to stem cell homing and play a role in the migration of leukemic cells [24]. To examine whether XAP could inhibit the migration of K562 cells through regulating the expression levels of 
SDF-1 and CXCR-4 in K562 cells, western blot assay was performed after XAP treatment. As shown in Figure 3F-3I, XAP treatment significantly reduced the expression level of SDF-1 and CXCR-4 in K562 cells in a dosedependent manner. These results suggest that XAP may down-regulate the expression of SDF-1 and CXCR-4, then regulate the homing and migration of CML cells.

\section{XAP down-regulated Wnt/ $\beta$-catenin signaling pathway in $\mathrm{K562}$ cells}

How does XAP induce apoptosis of K562 cells? Since Wnt/ $\beta$-catenin signaling pathway mediates the apoptosis of cells [25], we next examined whether XAP induced the apoptosis of K562 cells through this pathway. As shown in Figure 4A, 4B, $\beta$-catenin protein level was
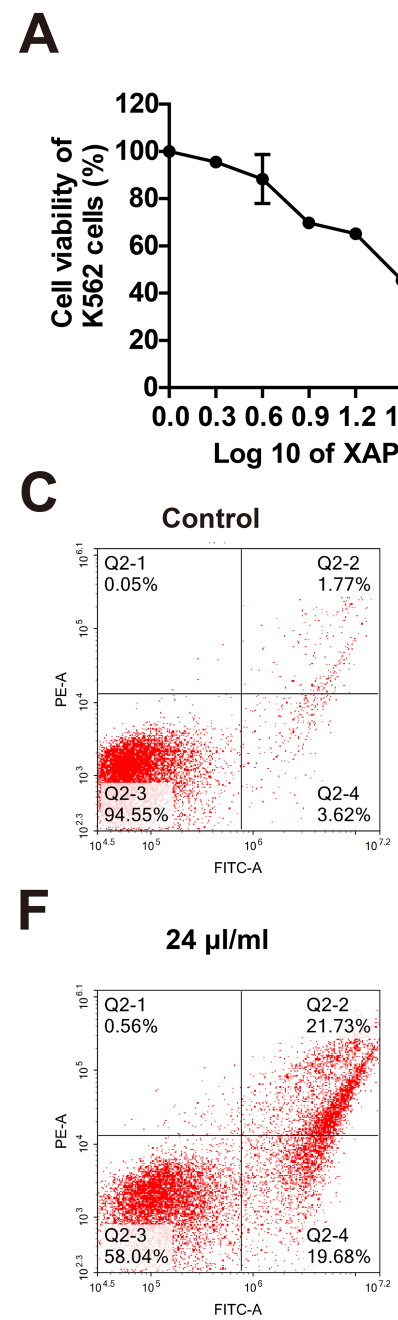

IC50 $31.77 \mu \mathrm{l} / \mathrm{ml}$

G
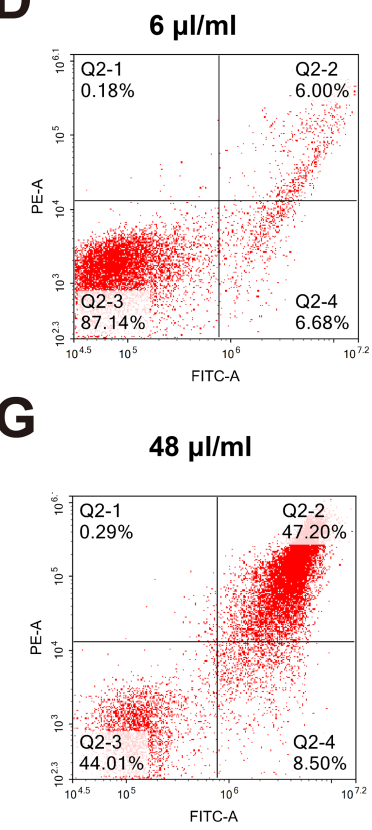

significantly down-regulated in K562 cells in a dosedependent manner after XAP treatment, whereas the inhibitor of $\beta$-catenin upstream signaling, the expression levels of p-GSK-3 $\beta$ (phospho-glycogen synthase kinase-3 $\beta$ ) and GSK-3 $\beta$ (glycogen synthasekinase$3 \beta$ ) protein were significantly increased in K562 cells in a dose-dependent manner (Figure 4A, 4C, 4D). We also detected the expression of downstream protein of $\beta$-catenin signaling, CyclinD1. Western blot results showed that after treated with XAP, CyclinD1 protein was also significantly down-regulated (Figure 4A, 4E). The message RNA (mRNA) expression levels of Wnt $\beta$ catenin signaling pathway were also detected. The results showed mRNA levels of $\beta$-catenin and CyclinD1 were significantly decreased in K562 cells after XAP treatment (Figure 4F, 4H), while mRNA level of GSK-3 $\beta$ was
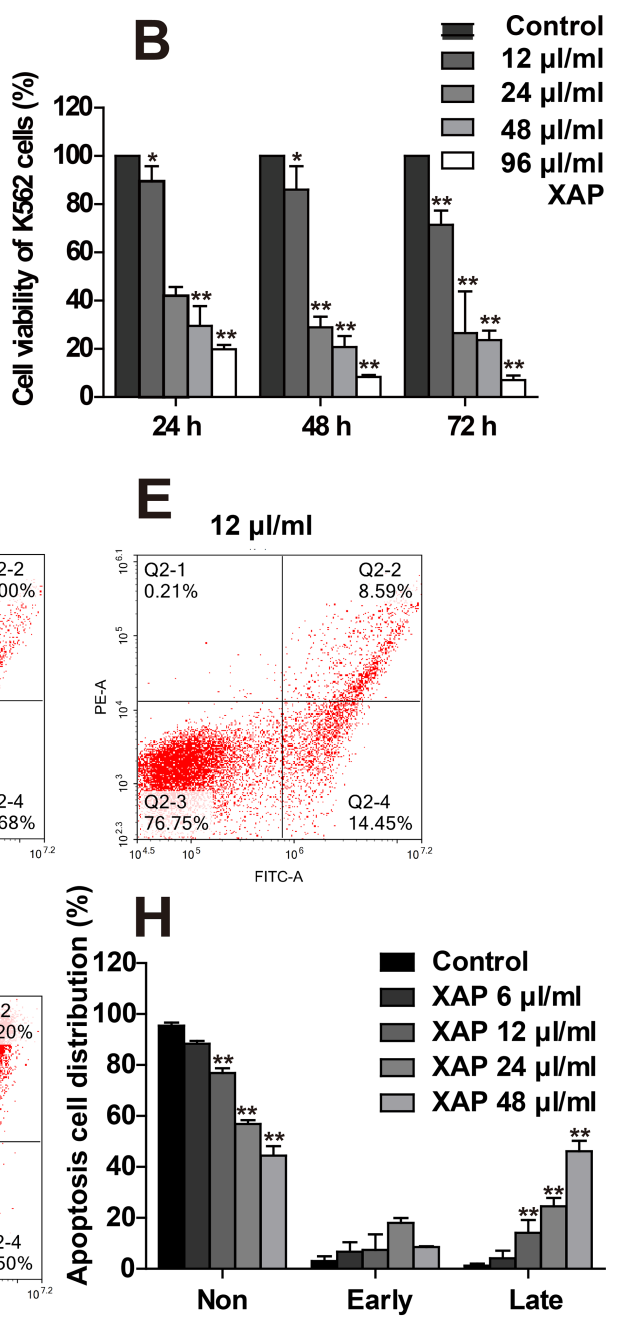

Figure 1: Xiao-Ai-Ping (XAP) treatment reduced the viability and promoted the apoptosis of K562 cells. (A) CCK8 assays detected the dose-dependent inhibition of K562 cell viability by XAP treatment after $24 \mathrm{~h}$. The results were shown as a feature of $\mu \mathrm{l}$ drug concentrations (log scale). The IC50 value was counted by SPSS21 software. (B) CCK8 assays detected time-dependent inhibition of K562 cell viability. K562 cells were treated with XAP (the concentration of XAP from 0 to $96 \mu \mathrm{l} / \mathrm{ml}$ ) after 24 h, 48 h and $72 \mathrm{~h}$. (C-G). Flow cytometric analysis were performed on K562 cells after $24 \mathrm{~h}$ of XAP treatment at a growing concentrations range (from 0 to $48 \mu \mathrm{l} /$ $\mathrm{ml}$ ) with AnnexinV-FITC/PI double-staining. (H). The apoptosis rates of K562 cells with ascending concentrations of XAP were analyzed quantitatively shown in C-G. Data were represented as mean $\pm \mathrm{SD}$ of three independent trails. Student's $t$-test, compared with control, ${ }^{*} P<$ 0.05 and ${ }^{* *} P<0.01$. The control was treated with RPMI 1640 . 
Table 1: Primer sequences of $\beta$-catenin, cyclin D1, GSK-3ß, GAPDH

\begin{tabular}{lll}
\hline Gene & Forward & Reverse \\
\hline$\beta$-catenin & GCCAAGTGGGTGGTATAGAGG & GCGGGACAAAGGGCAAGA \\
GSK3 $\beta$ & AGACGCTCCCTGTGATTTATG & AACAAGAGGTTCTGCGGTTT \\
cyclinD1 & AGGCGGAGGAGAACAAACAG & TGAGGCGGTAGTAGGACAGGA \\
GAPDH & CATCAATGGAAATCCCATCA & GACTCCACGACGTACTCAGC \\
\hline
\end{tabular}

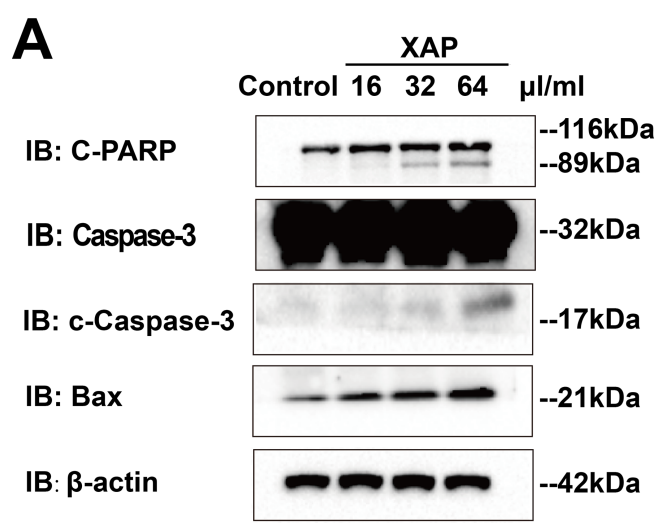

B Control $\frac{\text { XAP }}{16 \quad 32 \quad 64} \mu \mathrm{l} / \mathrm{ml}$

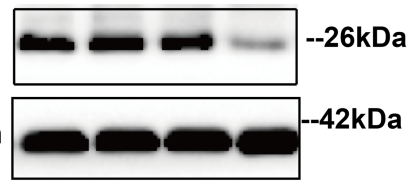

IB: $\beta$-actin

C

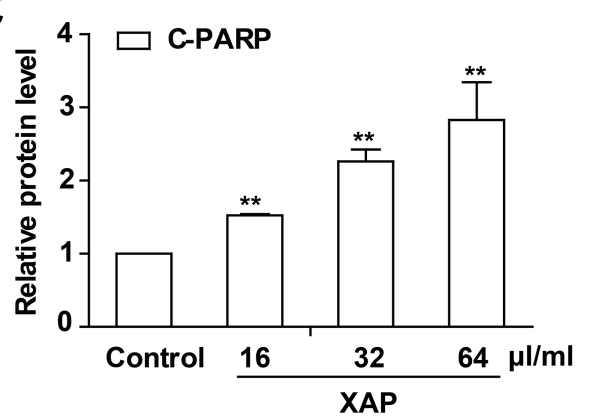

E

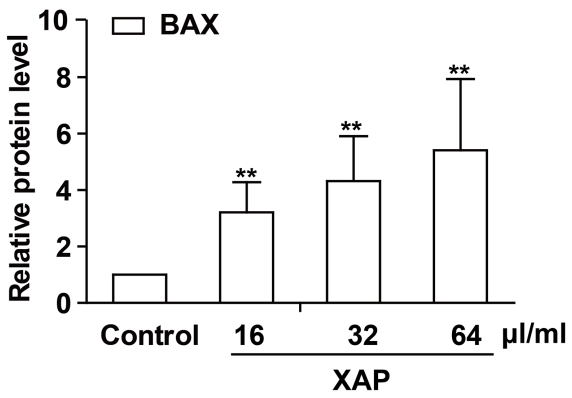

D

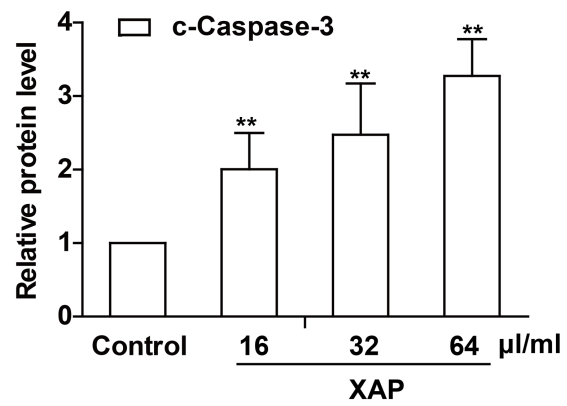

$\mathbf{F}$

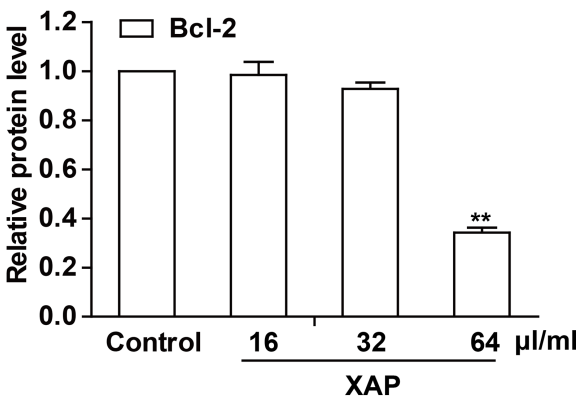

G

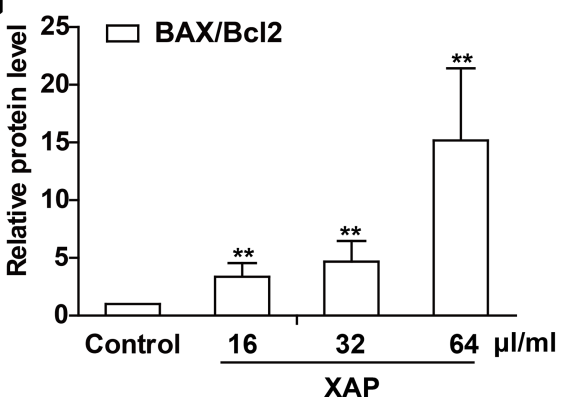

Figure 2: Effects of XAP treatment on the expression pattern of apoptosis-related downstream proteins in K562 cells. A-B. Western blot detected the expression of cleaved-PARP (c-PARP), cleaved caspase-3 (c-Caspase-3) and Bax (A), Bcl-2 (B) in K562 cells. Cells were treated with various concentrations of XAP (from 0 to $64 \mu \mathrm{l} / \mathrm{ml}$ ) after $24 \mathrm{~h}$. (C-G): The relative expression of the proteins described above (shown in A-B) and Bax/Bc12 ratio were analyzed quantitatively. Data were represented as mean $\pm \mathrm{SD}$ of three independent trails. Student's $t$-test, compared with control, ${ }^{*} P<0.05$ and ${ }^{* *} P<0.01$. The control was treated with RPMI 1640. 
significantly increased after XAP treatment (Figure 4G). Taken together, these results suggest that XAP treatment down-regulated Wnt/ $\beta$-catenin signaling pathway in K562 cells in the mRNA levels, which might mediate the XAPinduced apoptosis of K562 cells.

\section{Over-expression of $\beta$-catenin rescued the apoptosis of $\mathrm{K562}$ cells induced by XAP treatment}

To further examine whether down-regulating of Wnt/ $\beta$-catenin signaling mediated the apoptosis of K562 cells induced by XAP, we constructed $\beta$-catenin plasmid (blank $\mathrm{PV}$ vector) and transfected these plasmids into K562 cells to rescue the down-regulation of $\beta$-catenin by XAP. There was no significant difference between blank plasmid group and $\beta$-catenin plasmid group in apoptosis of K562 cells (Figure $5 \mathrm{~A}, 5 \mathrm{~B}, 5 \mathrm{E})$. However, after XAP $(30 \mu \mathrm{l} / \mathrm{ml})$ treatment, as shown in the Figure $5 \mathrm{C}, 5 \mathrm{D}, 5 \mathrm{E}$, flow cytometric analysis revealed that overexpression of $\beta$-catenin in K562 cells, indeed significantly restored XAP-induced apoptosis of K562 cells, compared with control group (blank constructs). Furthermore, western blot further revealed that $24 \mathrm{~h}$ after XAP $(30 \mu \mathrm{l} / \mathrm{ml})$ treatment, overexpression of $\beta$-catenin in
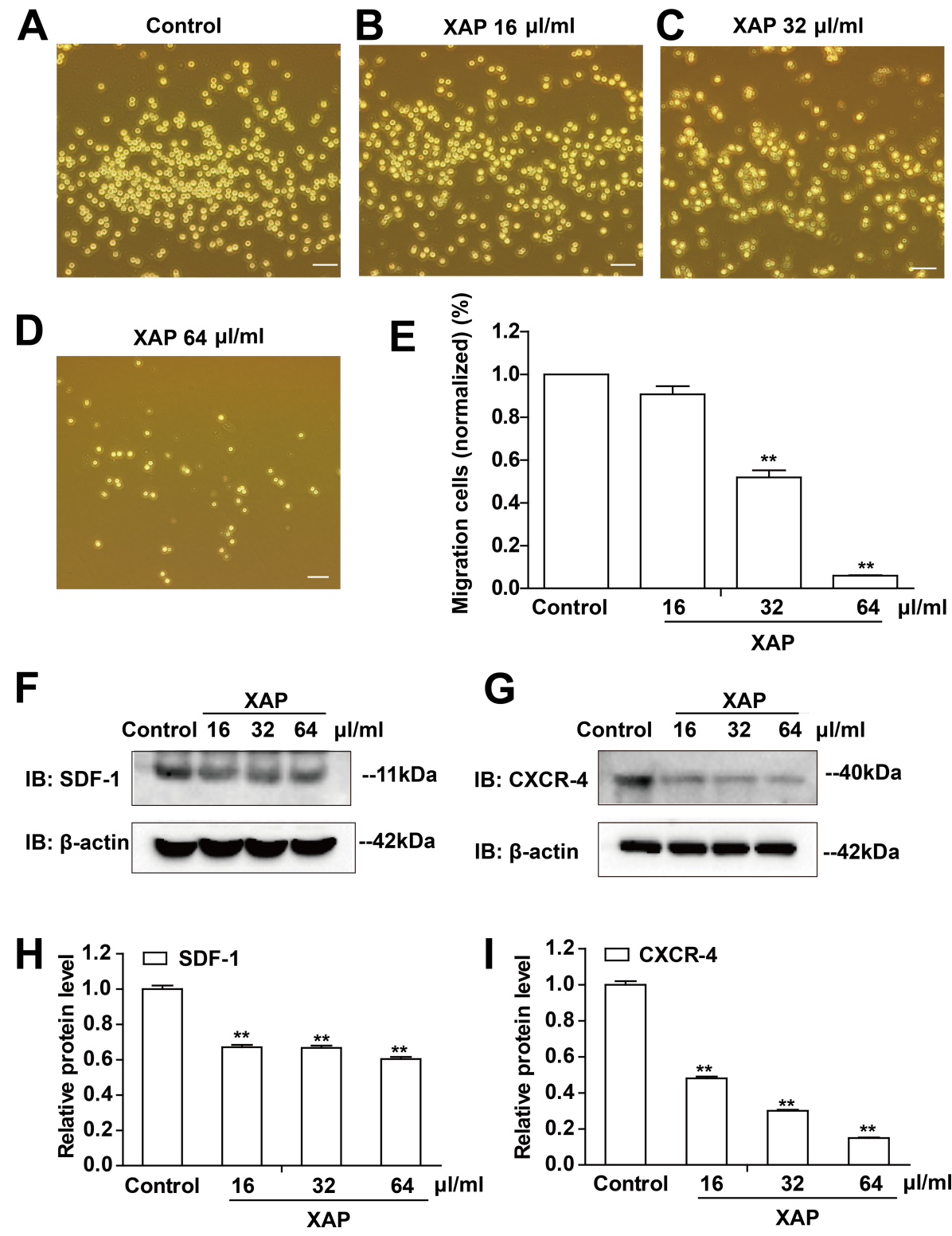

Figure 3: XAP treatment inhibited the migration of K562 cells. (A-D). Typical images of K562 cells treated by $0,16,32$ and $64 \mu \mathrm{l} / \mathrm{ml}$, respectively for $12 \mathrm{~h}$ in the transwell migration assay. (E) Quantitative analysis of the number of cells through the transwell membrane. K562 cells were treated with a growing concentration of XAP (from 0 to $64 \mu \mathrm{l} / \mathrm{ml}$ ) after $12 \mathrm{~h}$. (F-G). Western blot detected the expression of the chemokine SDF-1 and its receptor CXCR-4 proteins in K562 cells treated by different XAP concentrations. (HI) Quantitative analysis of the relative SDF-1 and CXCR-4 proteins expression levels. Data were represented as mean \pm SD of three independent trails. Student's $t$-test, compared with control, ${ }^{*} P<0.05$ and ${ }^{* *} P<0.01$. Control was treated with RPMI 1640. 
K562 cells, indeed significantly restored XAP-induced increase of Bax and decrease of $\mathrm{Bcl} 2$, compared with the blank plasmid transfection (Figure 6A, 6C-6E). Moreover, western blots also showed that the expression levels of other Wnt signaling pathway proteins, such as CyclinD1, p-GSK $3 \beta$ and GSK-3 $\beta$, were significantly restored in XAP $(30 \mu \mathrm{l} / \mathrm{ml})$-treated K562 cells by the overexpression of $\beta$-catenin, compared with blank construct (Figure 6B, $6 \mathrm{~F}-6 \mathrm{I})$. Taken together, these results suggest that overexpression of $\beta$-catenin rescued the apoptosis of K562 cells induced by XAP treatment.
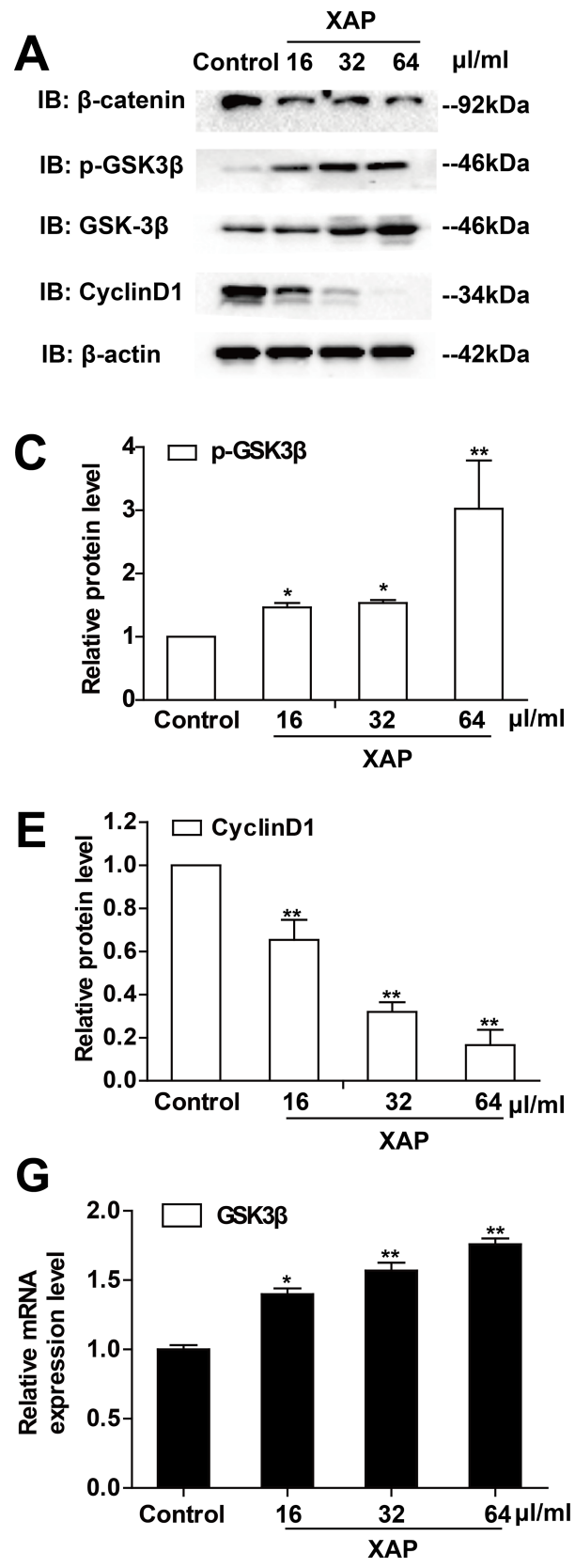

B
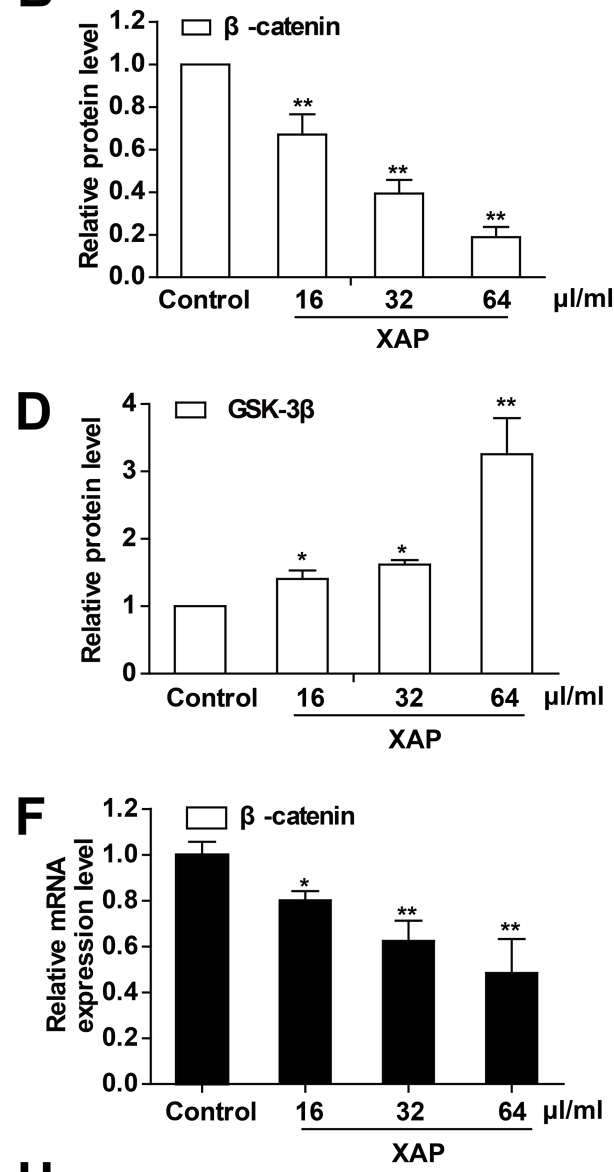

H

\section{XAP reduced the viability and promoted the apoptosis in PBMCs from CML patients}

To examine whether XAP has the similar effects on CML cells, PBMCs from 4 different CML patients and 4 different healthy people were collected and treated with XAP $(30 \mu \mathrm{l} / \mathrm{ml})$. As shown in Figure $7 \mathrm{~B}, 7 \mathrm{E}, 7 \mathrm{~F}$ and $7 \mathrm{H}$, XAP could significantly reduce the viability and increase the apoptosis of PBMCs from CML patients, compared with healthy people (Figure 7A, 7C, 7D and 7G) after XAP $(30 \mu \mathrm{l} / \mathrm{ml})$ treatment. These results suggest that

B

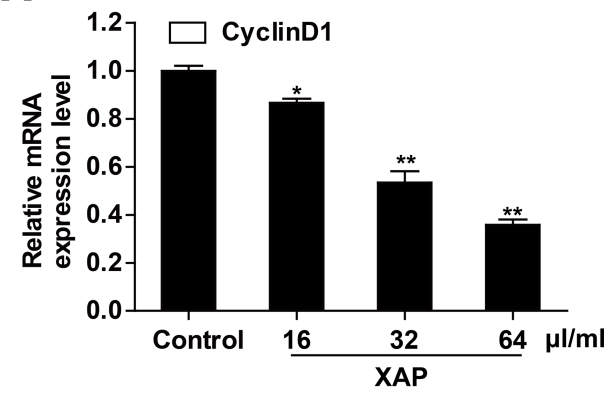

Figure 4: XAP treatment down-regulated Wnt/ $\boldsymbol{\beta}$-catenin signaling pathways in K562 cells. (A) Western blot detected the expression levels of Wnt signaling pathway proteins ( $\beta$-catenin, p-GSK3 $\beta$, GSK3 $\beta$, CyclinD1) in K562 cells under XAP concentrations. (B-E) Quantitative analysis the above proteins relative expression levels as shown in (A). (F-H) RT-PCR detected $\beta$-catenin, GSK3 $\beta$ and CyclinD1 mRNA expression levels and quantitative analysis the relative expression. Data were represented as mean \pm SD of three independent trails. Student's $t$-test, compared with control, ${ }^{*} P<0.05$ and ${ }^{* *} P<0.01$. Control was treated with RPMI 1640. 
effects of XAP on CML patients were similar to the effects of XAP on K562 cells. In summary, XAP might promote the apoptosis of CML patients PBMCs, suggesting the XAP might be a promising antitumor drug in curing CML.

\section{DISCUSSION}

In the present study we revealed that XAP suppressed the proliferation and promoted apoptosis of CML cells (K562 cell line) through inhibiting the Wnt/ $\beta$-catenin signaling pathway. We presented a potential therapeutic efficacy of XAP on CML cells. This study not only defines the XAP's function in anti-CML cells being a valuable adjuvant therapy for CML therapy but also
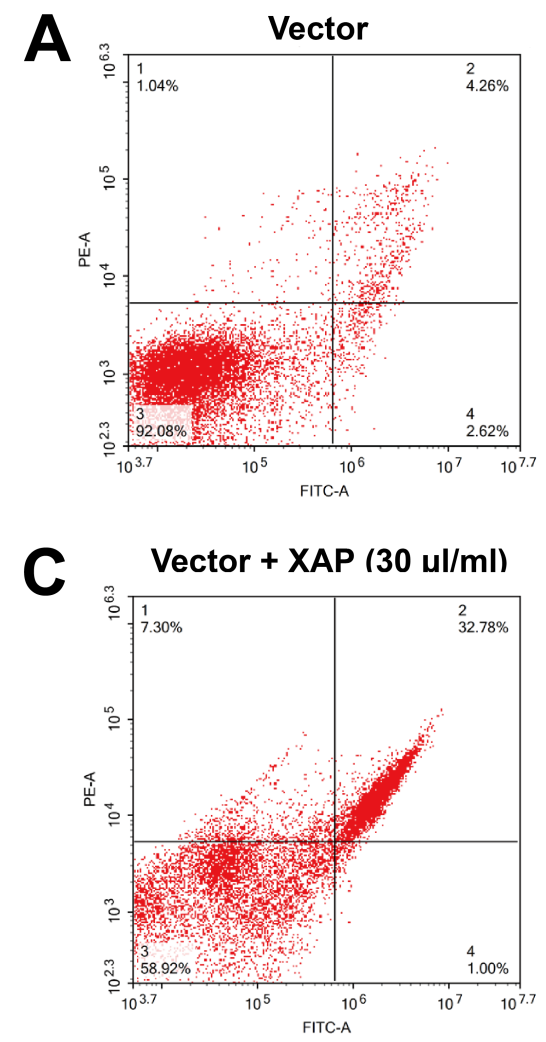

identifies a novel Wnt/ $\beta$-catenin signaling pathway related to XAP for the effects of XAP on CML cells.

$\mathrm{Wnt} / \beta$-catenin signaling pathway is well known to get involved in almost every aspects of tissues development and cellular homeostasis [26]. Wnt/ $\beta$-catenin signaling pathway includes Wnt (WNT family secretory protein), frizzled (Curl family transmembrane receptor), GSK-3 $\beta$ (glycogen synthase kinase- 3 , negative regulatory kinases), $\beta$-catenin (a cytoplasmic protein) and other proteins. Wnt ligands combine with receptor complexes which are made up by frizzled and LRP5/6 (low density lipoprotein receptor related protein 5/6) proteins. Then the complexes phosphorylate Dsh (dishevelled protein locates in cell membranes) and combine with Axin (tumor suppressor protein), leading to $\beta$-catenin
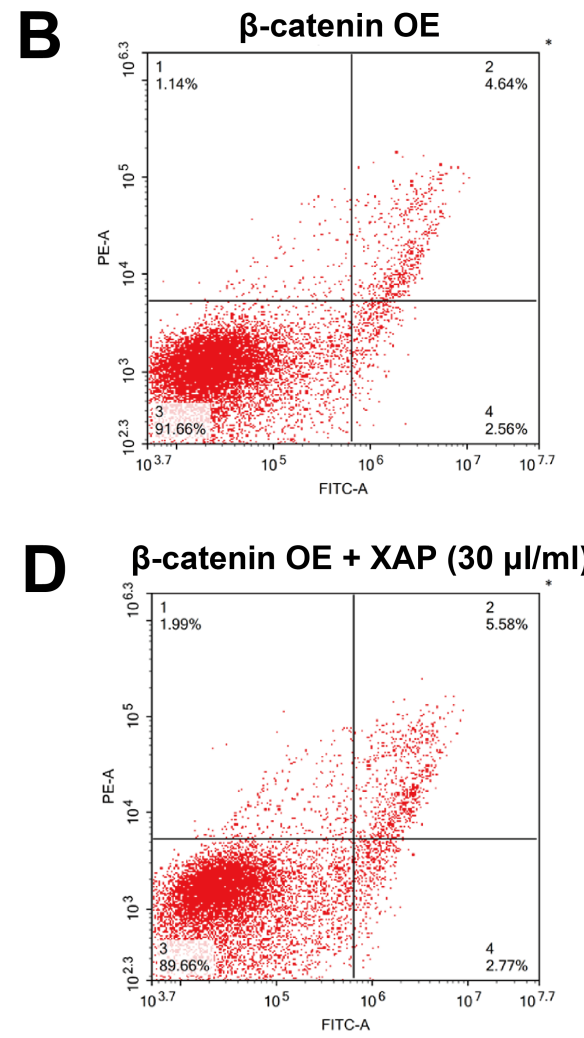

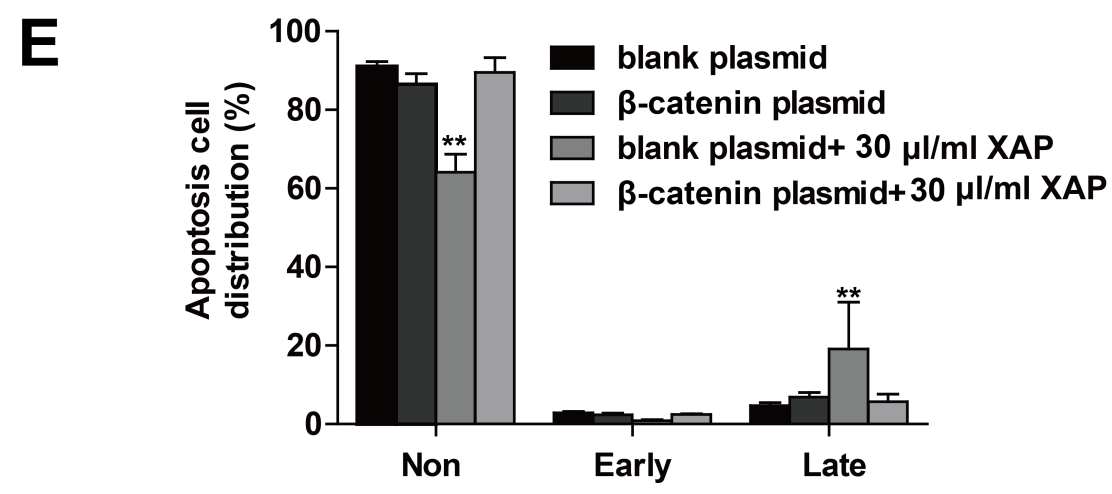

Figure 5: Over-expression of $\beta$-catenin rescued the apoptosis of K562 cells induced by XAP treatment. (A-D). Flow cytometric analysis by AnnexinV-FITC/PI double-staining were performed on K562 cells transfected with blank PV vector and the $\beta$-catenin plasmid, treated with XAP $(30 \mu \mathrm{l} / \mathrm{ml})$ for $48 \mathrm{~h}$. (E) The quantitative analysis of the apoptosis rate of K562 cells as shown in E. Student's $t$-test, compared with control (blank PV vector), ${ }^{*} P<0.05$ and ${ }^{* *} P<0.01$. OE: over-expression. 
destruction complex building up by GSK-3 $\beta$ 、Axin and APC (adenomatous polyposis coli) disintegration. $\beta$-catenin is fail to phosphorylate and degrade. The un-phosphorylated $\beta$-catenin accumulates in cytoplasm then translocates to the nucleus, integrateing with TCF/LEF (T cell factor/lymphoid enhance factor) and activating downstream events, such as CyclinD1, c-myc [27, 28].

The continuous activation of $\mathrm{Wnt} / \beta$-catenin signaling pathway is a key factor for tumorigenesis [29-31]. It also plays a key role in self-renewal of HSCs, accelerating $\mathrm{CML}$ progression and inducing $B C R-A B L$ kinase-independent resistance [32-45]. The controversies about the important roles of $\mathrm{Wnt} / \beta$-catenin signaling pathway in aspect of LSCs self-renewal have been thoroughly introduced [46]. Studies showed that when $\beta$-catenin was inhibited in mouse hematopoietic cells, the leukemic transformation mediated by $B C R-A B L$ were significantly decreased $[34,47]$. Combinatorial strategy (Combined inhibition of $B C R-A B L$ and $\beta$-catenin) showed better effect in CML therapy, even in TKI-resistant blast crisis (BC)-CML [48]. In contrast, Wnt/ $\beta$-catenin signaling pathway was activated once, progenitor cells resume selfrenewal ability, further resulting in tumor development, recrudescence and drugs resistance [49-51]. The current academic points of reasons leading to $B C R-A B L$ kinaseindependent resistance are mainly focused on two aspects:

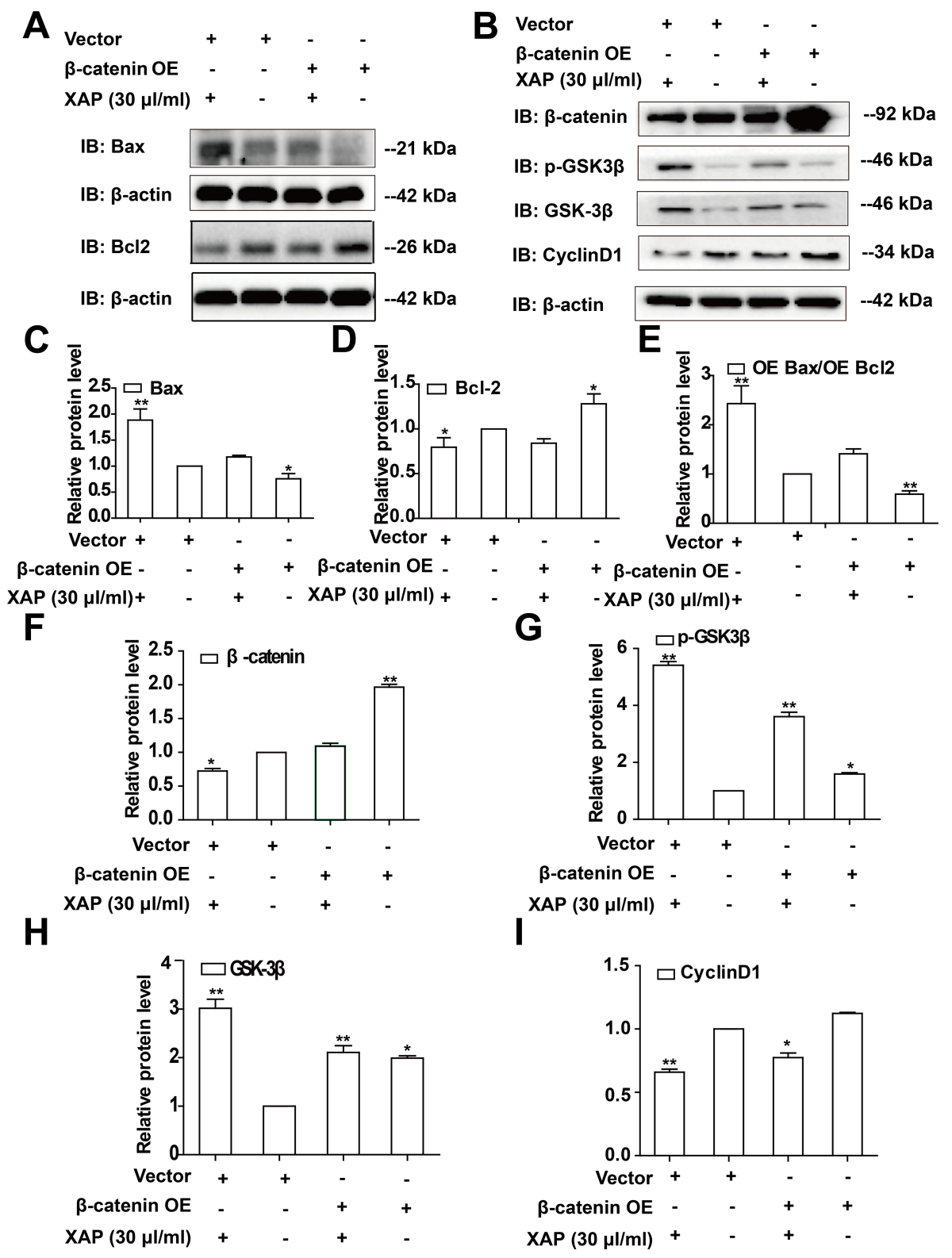

Figure 6: Over-expression of $\beta$-catenin rescued the apoptosis of $\mathrm{K562}$ cells and inactivation of downstream of Wnt/ $\beta$ catenin signaling in K562 cells induced by XAP treatment. (A) Western blot detected the expression level of Bax and Bcl2 proteins after blank PV vector and the $\beta$-catenin plasmid transfected. (B) Wnt signaling pathway proteins ( $\beta$-actenin, p-GSK3 $\beta$, GSK3 $\beta$ and CyclinD1) were detected. $(\mathbf{C}-\mathbf{I})$. Quantitative analysis of the relative protein expression levels. Data were represented as mean \pm SD of three independent trails. Student's $t$-test, compared with control (the blank plasmid). ${ }^{*} P<0.05$ and ${ }^{* *} P<0.01$. OE: over-expression. 

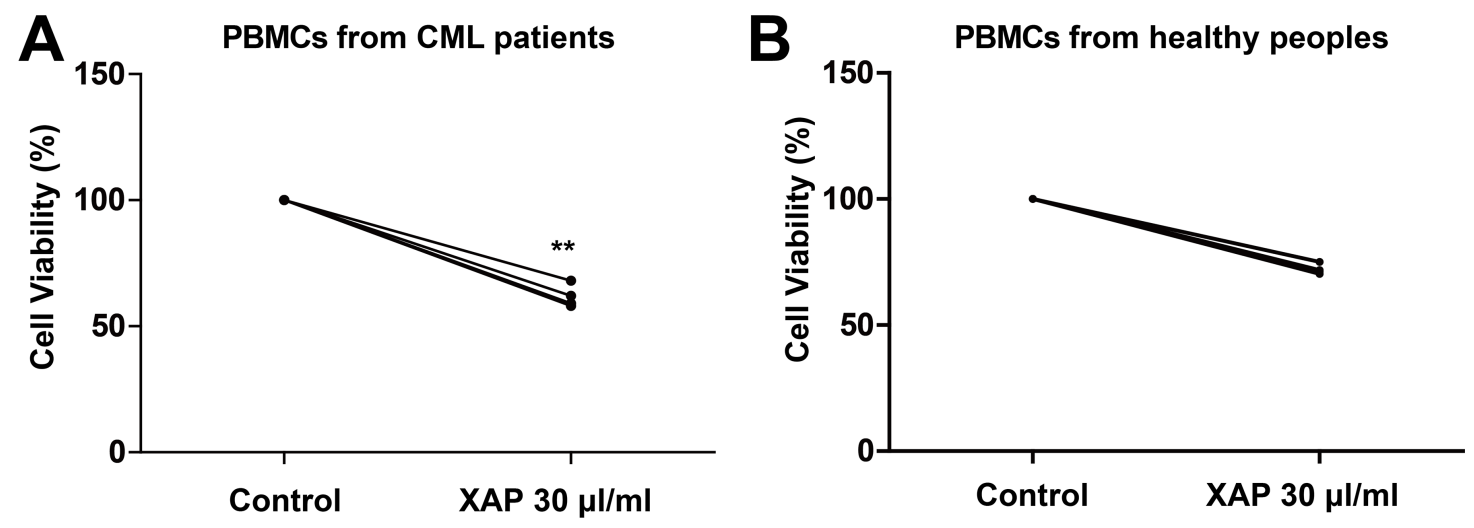

C

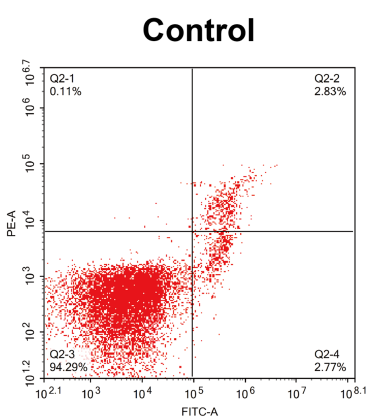

D

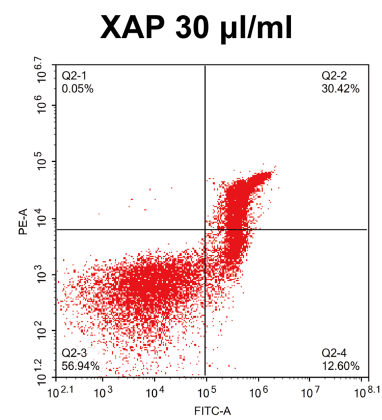

PBMCs from CML patients

E
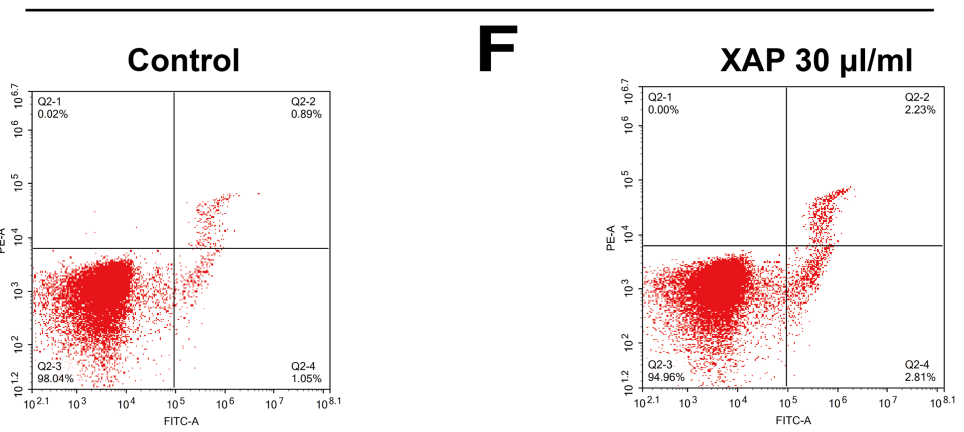

PBMCs from healthy peoples

G

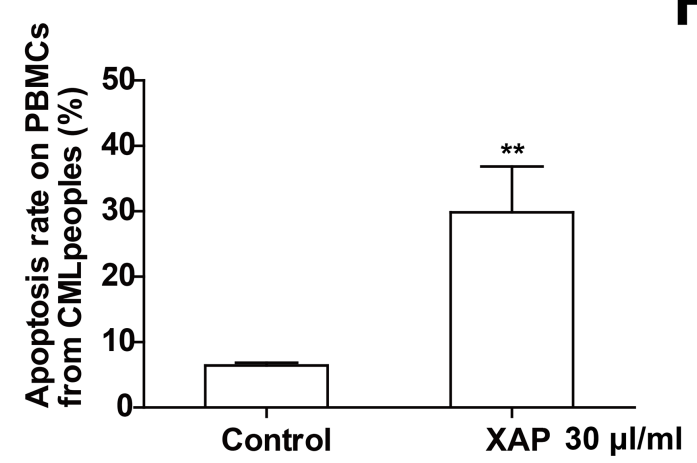

H

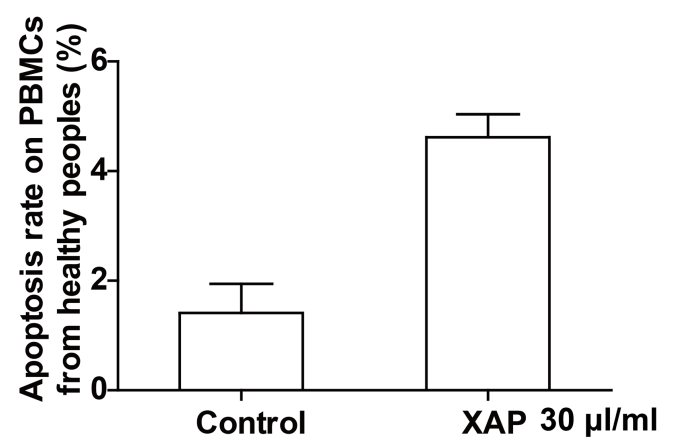

Figure 7: XAP reduced the viability and promoted the apoptosis of PBMCs from CML patients. (A-B) CCK8 assays were performed on PBMCs from healthy people (A) $(n=4)$ or CML patients $(\mathrm{B})(n=4)$ treated by XAP for 4 h. (C-D) Flow cytometric analysis were performed on PBMCs from healthy people after $4 \mathrm{~h}$ of control and XAP treatment at $30 \mu \mathrm{l} / \mathrm{ml}$ with AnnexinV-FITC/PI doublestaining. (E-F) Flow cytometric analysis were performed on PBMCs from CML patients after $4 \mathrm{~h}$ of control and XAP treatment at $30 \mu \mathrm{l} /$ $\mathrm{ml}$ with AnnexinV-FITC/PI double-staining. $(\mathbf{G}-\mathbf{H})$ Quantitative analysis of the apoptotic percentage of PBMCs from healthy people and CML patients, respectively. Data were represented as mean $\pm \mathrm{SD}\left({ }^{*} p<0.05\right.$ and $\left.{ }^{* *} p<0.01\right)$. Student's $t$-test, compared with control, ${ }^{*} P<$ 0.05 and $* * P<0.01$. Control was treated with RPMI 1640. 
activation of signaling pathways or extrinsic bone marrow (BM) microenvironmental conditions [42, 43, 45, 52]. In addition, nuclear $\beta$-catenin leads to cells TKI resistance, but not BM-caused TKI resistance [45].

Based on above evidences, inactivated the Wnt/ $\beta$ catenin signaling pathway and stabilization $\beta$-catenin in the cytoplasm are the key steps in CML therapy. In our study, we demonstrated that XAP promoted apoptosis and suppressed proliferation of K562 cells and PBMCs from CML patients, through antagonizing the $\mathrm{Wnt} / \beta$-catenin signaling pathway. We found that XAP treatment could down-regulate the expression of $\beta$-catenin, and up-regulate the GSK-3 $\beta$ and $\mathrm{p}$-GSK3 $\beta$ level, further inactivate CyclinD1. In addition, over-expression of $\beta$-catenin by transfection, restored XAP-induced apoptosis of K562 cells. These consequences intensely revealed that XAP could mediate the $\mathrm{Wnt} / \beta$-catenin signaling pathway and induce K562 cells apoptosis.

Beyond this, literatures revealed that other signaling pathways have been found involved in CML. In our study, we demonstrated that PTEN/PI3K/AKT signaling pathway and SDF1/CXCR4 axis were involved in XAPtreated K562 cells (some of data not shown). Some studies showed the crosstalk between Wnt/ $\beta$-catenin and PI3K/ AKT signaling pathways in other tumors $[53,54]$. And the key factor between two signaling is GSK-3 $\beta$. PI3K/AKT activation leads to GSK-3 $\beta$ phosphorylation, suppressed GSK-3 $\beta$ activity [55-57], and inhibited $\beta$-catenin degradation. However, the detailed relationships between two signaling pathways are still need further examinations in future.

In addition, XAP could also inhibit the activity of SDF1/CXCR4 axis, then further affect K562 cells migration. Chemokines are a family of small proinflammatory chemoattractant proteins that take part in many aspects of homeostatic process. SDF1/ CXCR4 mediates lymphocytes homing to secondary lymphoid organs, and is closely related to tumor process including metastasis, angiogenesis, and survival of tumor progression [58, 59]. SDF1, a homeostatic chemokine and the ligand of CXCR4, is produced by marrow-, lymph nodes-, muscle- and other types of cells [60]. CXCR4, is highly expressed on the membrane of normal hematopoietic cells and acute myeloid leukemic CD34 cells, CD34 ${ }^{+} 38^{-}$cells were also included [61], has been found to regulate the $\mathrm{CD} 34^{+}$stem cells homing to marrow microenvironment [62]. At present, the IM resistance is a big challenge for CML therapy, even patients get complete responses after IM therapy, the quiescent original cell still remain and resist to IM [63]. At present, the small molecule antagonists and blocking antibodies targeting to CXCR4, are still in the clinical trial stages $[64,65]$. The important role of SDF1/CXCR4 axis is well recognized in many kinds of hematologic malignancies [66-68], however the exact connection with CML is still need to be further explored. Our research provided a certain basis for the link between SDF1/CXCR4 axis and CML to a certain extent.

In Wnt signaling pathway, $G S K-3 \beta$ plays an important role in coordinating signal input, the key function is the phosphorylation and stability of $\beta$-catenin $[69,70]$. Meanwhile, studies have revealed that when inhibited $G S K-3 \beta$, the expression level of CXCR4 was also increased, then enhanced the mesenchymal stem cells (MSCs) migration [71, 72]. Simultaneously, when co-cultivate the CML cells and MSCs, IM could restore CXCR4 expression and further influence the CML cells migration to bone marrow stromal cells (BMSCs). This is closely related to the mechanism of CML relapse [73]. The crosstalk between Wnt pathway and SDF1/CXCR4

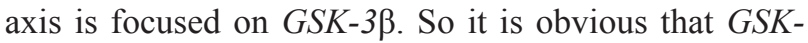
$3 \beta$ plays an important role in regulating SDF1/CXCR4 axis and Wnt pathway. However the definite connection between two pathways and the link with CML still need further explored. Our results showed that XAP reduced K562 cells migration significantly and restored SDF1/ CXCR4 expression. According to the references and results of experiments, XAP might play an important role in reducing recurrence/metastasis of patients who received IM therapy.

In this study, we mainly aimed at canonical Wnt pathway. Although previous studies have found that besides the canonical Wnt pathway, the non-canonical Wnt-pathway might also involve in the pathogenesis of CML [74]. Here we found that XAP could suppress the proliferation and promote the apoptosis of K562 cells, through inhibiting $\mathrm{Wnt} / \beta$-catenin signaling pathway. Our studies represented a novel strategy for CML therapy, and the underlying mechanism.

\section{MATERIALS AND METHODS}

\section{XAP injection preparation}

XAP injection (Crude drug concentration $5 \mathrm{~g} / \mathrm{ml}$ ) was purchased from Sanhome Pharmaceutical Co., Ltd (Nanjing, China) and stored at $4^{\circ} \mathrm{C}$. In vitro experiments, XAP was diluted in RPMI 1640 (from Gibco, Carlsbad, CA, USA).

\section{Cell lines and culture conditions}

Human chronic myelogenous leukemia cell line K562 were purchased from cell bank of the Chinese Academy of Science (Shanghai, China) and cultured in RPMI 1640 containing with $10 \%$ fetal bovine serum (FBS) (from Gibco, Carlsbad, CA, USA) and $100 \mathrm{U} / \mathrm{ml}$ of penicillin-streptomycin at $37^{\circ} \mathrm{C}$ saturated humidity containing 5\% $\mathrm{CO}_{2}$. Logarithmically growing cells (4-6 $\times$ $10^{5}$ cells $/ \mathrm{ml}$ ) were used to perform following experiments.

PBMCs were collected from CML patients, on the basis of obtaining patients' Informed Consent Form. Then 
apply Ficoll (TBD, HaoYang, Tianjin, China) to extract PBMCs. 4 diagnosed CML patients whose original cells in peripheral blood accounted for more than $70 \%$ from Zhejiang Provincial People's Hospital (Oct, 2016-Feb, 2017) and 4 healthy people were accepted with Informed Consent. Collect $4 \mathrm{ml}$ anti-coagulated blood from every people. Take anti-coagulated blood and mix well with the same amount of PBS solution, then was layered onto $4 \mathrm{ml}$ Ficoll-Paque. After centrifuge $2000 \mathrm{rpm} \times$ $20 \mathrm{~min}$, liquid was divided into three layers and middle layer was collected and diluted with $20 \mathrm{ml}$ RPMI 1640, then centrifuge $2000 \mathrm{rpm}$ for another $10 \mathrm{~min}$. Discard the supernatant and re-suspended PBMCs and cultured in RPMI 1640 containing with $10 \%$ fetal bovine serum (FBS). Exposed cells to XAP $(30 \mu \mathrm{l} / \mathrm{ml})$ treatment. The control group cells were cultured with RPMI 1640.

\section{Proliferation assay (CCK-8 assay)}

The effects of XAP on viability and proliferation of $\mathrm{K} 562$ cells were assessed by CCK8 colorimetric assays according to the previous described [75]. Briefly, seed exponentially growing K562 cells in 96-well plates at a density of $2.0 \times 10^{4}$ cells/well in $100 \mu 1$ RPMI 1640 medium then exposed to XAP with concentrations of 0 (control group cells were treated with RPMI 1640), 12, 24,48 and $96 \mu \mathrm{l} / \mathrm{ml}$ for 24,48 and $72 \mathrm{~h}$, respectively. Each group included 3 parallel wells, then added CCK- 8 to each well. After $2 \mathrm{~h}$ incubation, the absorbance was measured at $450 \mathrm{~nm}$ using a micro-plate reader (BIOTEK, Vermont, USA). Cell viability was calculated by this: Cell viability $(\%)=(\mathrm{OD}$ treatment-OD blank $) /(\mathrm{OD}$ controlOD blank).

\section{Cell apoptosis assay}

AnnexinV/PI assay K562 cells were exposed for 24 $\mathrm{h}$ to various concentrations of XAP, the control cells were also treated with RPMI 1640. After treatment, cells were washed by PBS twice, then cells underwent AnnexinV/PI double staining for cell death assays (Beyotime, Haimen, China) according to manufacturer's protocol. The percentages of early and late stages of apoptosis cells were measured by flow cytometry (ACEA NovoCyte, USA).

\section{Migration analysis}

K562 cells were cultivated with XAP at 16, 32, 64 $\mu \mathrm{l} / \mathrm{ml}$, respectively for $12 \mathrm{~h}$, the control cells were treated with RPMI 1640 as usual. Treated cells were washed by PBS twice, then $5 \times 10^{4}$ cells were resuspended with 200 $\mu \mathrm{l}$ serum-free medium and seeded in transwells (purchased from Corning, NY, USA). Each transwell was put in 24well plate contained with $400 \mu \mathrm{l}$ RPMI 1640 medium supplement with $10 \%$ FBS. After $12 \mathrm{~h}$, the migrated cells were observed by light microscope.

\section{Western blot analysis}

K562 cells were treated with XAP at 16, 32 and $64 \mu \mathrm{l} / \mathrm{ml}$ for $24 \mathrm{~h}$, respectively, the control cells were also treated with RPMI 1640, after treatment, then tumor cells were washed by PBS for twice. Remove supernatant and cells were lysed with RIPA added PMSF (Beyotime, Haimen, China) for $30 \mathrm{~min}$ at $4^{\circ} \mathrm{C}$. After this, the concentration of harvested proteins were measured by protein assay kit (Thermo). Next, the same amount of proteins were collected and separated by $12 \%$ SDSpolyacrylamide gel electrophoresis. Then proteins were transferred to polyvinylidene fluoride (PVDF) membranes (ImmunobilinP; Millipore) then used 10\% skim milk to block proteins for $1 \mathrm{~h}$. The blots were detected with primary antibodies against $\beta$-actin (1:1000, abcam, USA), Bax (1:1000, Cell Signaling Technology, USA), Bcl2 (1:1000, Cell Signaling Technology, USA), c-Caspase-3 (1:1000, abcam, USA), cleaved-PARP (1:1000, Cell Signaling Technology, USA), $\beta$-catenin $(1: 1000$, Cell Signaling Technology, USA), GSK-3 $\beta$ (1:1000, Cell Signaling Technology, USA), p-GSK3 $\beta$ (1:1000, Cell Signaling Technology, USA), CyclinD1 (1:1000, abcam, USA), PTEN (1:1000, Cell Signaling Technology, USA), AKT (1:1000, Cell Signaling Technology, USA), p-AKT (1:1000, Cell Signaling Technology, USA), PI3K (1:1000, Cell Signaling Technology, USA), SDF-1 (1:1000, abcam, USA), CXCR4 (1:1000, abcam, USA), CD44 (1:1000, abcam, USA) at $4^{\circ} \mathrm{C}$ incubation overnight. Then, wash away the primary antibodies, the corresponding secondary antibodies were added (1:5000, Beyotime) for $1 \mathrm{~h}$ at room temperature, at last, the enhanced chemiluminescence (ECL) solution (Amersham Biosciences) was used to detect the target bands. The gray values of membrane signals were measured by Gel-Pro-Analyzer software (Bethesda, MD, USA) and the results were calculated. $\beta$-actin served as loading control.

\section{Reverse transcription-PCR (RT-PCR) assay}

K562 cells were cultured with XAP at 01632 and $64 \mu \mathrm{l} / \mathrm{ml}$ for $24 \mathrm{~h}$, respectively, the control cells were also treated with RPMI 1640, after XAP incubation, the mRNA from K562 cells was extracted (MagnaPure LC RNA Isolation Kit; Roche Applied Science) and underwent reverse transcription into cDNA according to Transcription High Fidelity cDNA Synthesis kit (Roche Applied Science) respectively following the corresponding manufacturer's instructions. With template DNA prepared, the parameter of amplification reaction was as follows: 3 min at $95^{\circ} \mathrm{C}$ followed by 40 cycles for $10 \mathrm{sec}$ at $95^{\circ} \mathrm{C}, 30$ sec at $60^{\circ} \mathrm{C}$. And primer pairs were as Table 1 :

\section{Cell transfection}

$\beta$-catenin was constructed into PV vectors and was transfected into K562 cells with lipofectamine 
3000 (Invitrogen, USA) following the manufacturer's instructions. $24 \mathrm{~h}$ after transfection, cells $\left(1 \times 10^{6} / \mathrm{ml}\right)$ were treated with XAP $(30 \mu \mathrm{l} / \mathrm{ml})$ for $48 \mathrm{~h}$. The apoptosis of cells count was determined by flow cytometry and some related proteins were detected by western blot.

\section{Statistics}

All data were presented as standard deviation (SD), results expressed from at least 3 independent experiments. Effects of difference between control and XAP treatments were analyzed by Student's $t$-test, performed by the SPSS statistics 21.0. $p<0.05$ was defined as significant statistically.

\section{ACKNOWLEDGMENTS AND GRANT SUPPORT}

This study was supported by Zhejiang Provincial Natural Science Foundation (Q17H090034, LY15C090006), Science and Technology Planning Project of Zhejiang Province (2017C33197), Medical and Health Science and Technology Project of Zhejiang Province (2017KY209), Outstanding Youth Foundation of Zhejiang Provincial People's Hospital (ZRY2016B007, ZRY2016A003).

\section{CONFLICTS OF INTEREST}

The authors declare no conflicts of interest.

\section{REFERENCES}

1. Eck MJ, Manley PW. The interplay of structural information and functional studies in kinase drug design: insights from BCR-Abl. Current opinion in cell biology. 2009; 21:288295.

2. Rowley JD. Letter: A new consistent chromosomal abnormality in chronic myelogenous leukaemia identified by quinacrine fluorescence and Giemsa staining. Nature. 1973; 243:290-293.

3. Ben-Neriah Y, Daley GQ, Mes-Masson AM, Witte ON, Baltimore D. The chronic myelogenous leukemia-specific P210 protein is the product of the bcr/abl hybrid gene. Science (New York, NY). 1986; 233:212-214.

4. Bartram CR, de Klein A, Hagemeijer A, van Agthoven T, Geurts van Kessel A, Bootsma D, Grosveld G, FergusonSmith MA, Davies T, Stone M, et al. Translocation of c-ab1 oncogene correlates with the presence of a Philadelphia chromosome in chronic myelocytic leukaemia. Nature. 1983; 306:277-280.

5. Groffen J, Stephenson JR, Heisterkamp N, de Klein A, Bartram CR, Grosveld G. Philadelphia chromosomal breakpoints are clustered within a limited region, bcr, on chromosome 22. Cell. 1984; 36:93-99.
6. Lugo TG, Pendergast AM, Muller AJ, Witte ON. Tyrosine kinase activity and transformation potency of bcr-abl oncogene products. Science (New York, NY). 1990; 247:1079-1082.

7. Dalgic CT, Kaymaz BT, Ozkan MC, Dalmizrak A, Sahin F, Saydam G. Investigating the Role of JAK/STAT Pathway on Dasatinib-Induced Apoptosis for CML Cell Model K562. Clinical lymphoma, myeloma \& leukemia. 2015; 15:161-166.

8. Nieborowska-Skorska M, Wasik MA, Slupianek A, Salomoni P, Kitamura T, Calabretta B, Skorski T. Signal transducer and activator of transcription (STAT) 5 activation by $\mathrm{BCR} / \mathrm{ABL}$ is dependent on intact Src homology $(\mathrm{SH}) 3$ and $\mathrm{SH} 2$ domains of $\mathrm{BCR} / \mathrm{ABL}$ and is required for leukemogenesis. The Journal of experimental medicine. 1999; 189:1229-1242.

9. Sillaber C, Gesbert F, Frank DA, Sattler M, Griffin JD. STAT5 activation contributes to growth and viability in Bcr/ Abl-transformed cells. Blood. 2000; 95:2118-2125.

10. Daley GQ, Van Etten RA, Baltimore D. Induction of chronic myelogenous leukemia in mice by the P210bcr/abl gene of the Philadelphia chromosome. Science (New York, NY). 1990; 247:824-830.

11. Cortes J, Hochhaus A, Hughes T, Kantarjian H. Front-line and salvage therapies with tyrosine kinase inhibitors and other treatments in chronic myeloid leukemia. Journal of clinical oncology : official journal of the American Society of Clinical Oncology. 2011; 29:524-531.

12. Lee F, Fandi A, Voi M. Overcoming kinase resistance in chronic myeloid leukemia. The international journal of biochemistry \& cell biology. 2008; 40:334-343.

13. Shah NP, Nicoll JM, Nagar B, Gorre ME, Paquette RL, Kuriyan J, Sawyers CL. Multiple BCR-ABL kinase domain mutations confer polyclonal resistance to the tyrosine kinase inhibitor imatinib (STI571) in chronic phase and blast crisis chronic myeloid leukemia. Cancer cell. 2002; 2:117-125.

14. Weisberg E, Manley PW, Cowan-Jacob SW, Hochhaus A, Griffin JD. Second generation inhibitors of BCR-ABL for the treatment of imatinib-resistant chronic myeloid leukaemia. Nature reviews Cancer. 2007; 7:345-356.

15. Hochhaus A, Baccarani M, Deininger M, Apperley JF, Lipton JH, Goldberg SL, Corm S, Shah NP, Cervantes F, Silver RT, Niederwieser D, Stone RM, Dombret H, et al. Dasatinib induces durable cytogenetic responses in patients with chronic myelogenous leukemia in chronic phase with resistance or intolerance to imatinib. Leukemia. 2008; 22:1200-1206.

16. Kantarjian HM, Giles FJ, Bhalla KN. Update on imatinibresistant chronic myeloid leukemia patients in chronic phase (CML-CP) on nilotinib therapy at 24 months: Clinical response, safety, and long-term outcomes. Blood. 2009; 114:464-464.

17. Cortes JE, Kantarjian HM, Brummendorf TH, Kim DW, Turkina AG, Shen ZX, Pasquini R, Khoury HJ, Arkin 
S, Volkert A, Besson N, Abbas R, Wang J, et al. Safety and efficacy of bosutinib (SKI-606) in chronic phase Philadelphia chromosome-positive chronic myeloid leukemia patients with resistance or intolerance to imatinib. Blood. 2011; 118:4567-4576.

18. Nicolini FE, Mauro MJ, Martinelli G, Kim DW, Soverini S, Muller MC, Hochhaus A, Cortes J, Chuah C, Dufva IH, Apperley JF, Yagasaki F, Pearson JD, et al. Epidemiologic study on survival of chronic myeloid leukemia and $\mathrm{Ph}(+)$ acute lymphoblastic leukemia patients with BCR-ABL T315I mutation. Blood. 2009; 114:5271-5278.

19. Cailleteau C, Micallef L, Lepage C, Cardot PJ, Beneytout JL, Liagre B, Battu S. Investigating the relationship between cell cycle stage and diosgenin-induced megakaryocytic differentiation of HEL cells using sedimentation field-flow fractionation. Analytical and bioanalytical chemistry. 2010; 398:1273-1283.

20. Leger DY, Liagre B, Beneytout JL. Role of MAPKs and NF-kappaB in diosgenin-induced megakaryocytic differentiation and subsequent apoptosis in HEL cells. International journal of oncology. 2006; 28:201-207.

21. Cragg GM, Newman DJ. Nature: a vital source of leads for anticancer drug development. Phytochemistry Reviews. 2009; 8:313-331.

22. Ruan WJ, Lai MD, Zhou JG. Anticancer effects of Chinese herbal medicine, science or myth? J Zhejiang Univ Sci B. 2006; 7:1006-1014.

23. Xue HL, Huang XD, He D, Lin SJ, Wang S, Niu T. [Effects of Marsdenia tenacissima extract on proliferation and apoptosis of hematologic neoplasm cell line cells]. Sichuan da xue xue bao Yi xue ban = Journal of Sichuan University Medical science edition. 2012; 43:174-179. [Article in Chinese].

24. Ghadge SK, Muhlstedt S, Ozcelik C, Bader M. SDF-1alpha as a therapeutic stem cell homing factor in myocardial infarction. Pharmacology \& therapeutics. 2011; 129:97-108.

25. Veeman MT, Axelrod JD, Moon RT. A second canon. Functions and mechanisms of beta-catenin-independent Wnt signaling. Developmental cell. 2003; 5:367-377.

26. Moon RT, Kohn AD, De Ferrari GV, Kaykas A. WNT and beta-catenin signalling: diseases and therapies. Nature reviews Genetics. 2004; 5:691-701.

27. Rakheja D, Cunningham JC, Mitui M, Patel AS, Tomlinson GE, Weinberg AG. A subset of cranial fasciitis is associated with dysregulation of the Wnt/beta-catenin pathway. Modern pathology : an official journal of the United States and Canadian Academy of Pathology, Inc. 2008; 21:1330-1336.

28. Staal FJ, Famili F, Garcia Perez L, Pike-Overzet K. Aberrant Wnt Signaling in Leukemia. Cancers. 2016; 8.

29. Clevers H. Wnt/beta-catenin signaling in development and disease. Cell. 2006; 127:469-480.

30. MacDonald BT, Tamai K, He X. Wnt/beta-catenin signaling: components, mechanisms, and diseases. Developmental cell. 2009; 17:9-26.
31. Moon RT, Bowerman B, Boutros M, Perrimon N. The promise and perils of Wnt signaling through beta-catenin. Science (New York, NY). 2002; 296:1644-1646.

32. Abrahamsson AE, Geron I, Gotlib J, Dao KH, Barroga CF, Newton IG, Giles FJ, Durocher J, Creusot RS, Karimi M, Jones C, Zehnder JL, Keating A, et al. Glycogen synthase kinase 3 beta missplicing contributes to leukemia stem cell generation. Proceedings of the National Academy of Sciences of the United States of America. 2009; 106:3925-3929.

33. Wang Y, Krivtsov AV, Sinha AU, North TE, Goessling W, Feng Z, Zon LI, Armstrong SA. The Wnt/beta-catenin pathway is required for the development of leukemia stem cells in AML. Science (New York, NY). 2010; 327:16501653.

34. Zhao C, Blum J, Chen A, Kwon HY, Jung SH, Cook JM, Lagoo A, Reya T. Loss of beta-catenin impairs the renewal of normal and CML stem cells in vivo. Cancer cell. 2007; 12:528-541.

35. Heidel FH, Bullinger L, Feng Z, Wang Z, Neff TA, Stein L, Kalaitzidis D, Lane SW, Armstrong SA. Genetic and pharmacologic inhibition of beta-catenin targets imatinibresistant leukemia stem cells in CML. Cell stem cell. 2012; 10:412-424.

36. Hamilton A, Helgason GV, Schemionek M, Zhang B, Myssina S, Allan EK, Nicolini FE, Muller-Tidow C, Bhatia R, Brunton VG, Koschmieder S, Holyoake TL. Chronic myeloid leukemia stem cells are not dependent on Bcr-Abl kinase activity for their survival. Blood. 2012; 119:1501-1510.

37. Jamieson $\mathrm{CH}$. Chronic myeloid leukemia stem cells. Hematology American Society of Hematology Education Program. 2008:436-442.

38. Perrotti D, Jamieson C, Goldman J, Skorski T. Chronic myeloid leukemia: mechanisms of blastic transformation. The Journal of clinical investigation. 2010; 120:2254-2264.

39. Jamieson CH, Ailles LE, Dylla SJ, Muijtjens M, Jones C, Zehnder JL, Gotlib J, Li K, Manz MG, Keating A, Sawyers CL, Weissman IL. Granulocyte-macrophage progenitors as candidate leukemic stem cells in blast-crisis CML. The New England journal of medicine. 2004; 351:657-667.

40. Minami Y, Stuart SA, Ikawa T, Jiang Y, Banno A, Hunton IC, Young DJ, Naoe T, Murre C, Jamieson CH, Wang JY. BCR-ABL-transformed GMP as myeloid leukemic stem cells. Proceedings of the National Academy of Sciences of the United States of America. 2008; 105:17967-17972.

41. Giotopoulos G, van der Weyden L, Osaki H, Rust AG, Gallipoli P, Meduri E, Horton SJ, Chan WI, Foster D, Prinjha RK, Pimanda JE, Tenen DG, Vassiliou GS, et al. A novel mouse model identifies cooperating mutations and therapeutic targets critical for chronic myeloid leukemia progression. The Journal of experimental medicine. 2015; 212:1551-1569.

42. Neviani P, Harb JG, Oaks JJ, Santhanam R, Walker CJ, Ellis JJ, Ferenchak G, Dorrance AM, Paisie CA, Eiring AM, Ma Y, Mao HC, Zhang B, et al. PP2A-activating 
drugs selectively eradicate TKI-resistant chronic myeloid leukemic stem cells. The Journal of clinical investigation. 2013; 123:4144-4157.

43. Zhang B, Li M, McDonald T, Holyoake TL, Moon RT, Campana D, Shultz L, Bhatia R. Microenvironmental protection of CML stem and progenitor cells from tyrosine kinase inhibitors through N-cadherin and Wnt-beta-catenin signaling. Blood. 2013; 121:1824-1838.

44. Kleppe M, Levine RL. Targeting beta-catenin in CML: leukemia stem cells beware! Cell stem cell. 2012; 10:351353.

45. Eiring AM, Khorashad JS, Anderson DJ, Yu F, Redwine HM, Mason CC, Reynolds KR, Clair PM, Gantz KC, Zhang TY, Pomicter AD, Kraft IL, Bowler AD, et al. beta-Catenin is required for intrinsic but not extrinsic BCR-ABL1 kinaseindependent resistance to tyrosine kinase inhibitors in chronic myeloid leukemia. Leukemia. 2015; 29:2328-2337.

46. Lento W, Congdon K, Voermans C, Kritzik M, Reya T. Wnt signaling in normal and malignant hematopoiesis. Cold Spring Harbor perspectives in biology. 2013; 5.

47. Staal FJ, Clevers HC. WNT signalling and haematopoiesis: a WNT-WNT situation. Nature reviews Immunology. 2005; 5:21-30.

48. Zhou H, Mak PY, Mu H, Mak DH, Zeng Z, Cortes J, Liu $\mathrm{Q}$, Andreeff M, Carter BZ. Combined inhibition of betacatenin and Bcr-Abl synergistically targets tyrosine kinase inhibitor-resistant blast crisis chronic myeloid leukemia blasts and progenitors in vitro and in vivo. Leukemia. 2017.

49. Huntly BJ, Gilliland DG. Leukaemia stem cells and the evolution of cancer-stem-cell research. Nature reviews Cancer. 2005; 5:311-321.

50. de Sousa EM, Vermeulen L, Richel D, Medema JP. Targeting Wnt signaling in colon cancer stem cells. Clinical cancer research : an official journal of the American Association for Cancer Research. 2011; 17:647-653.

51. Dodge ME, Lum L. Drugging the cancer stem cell compartment: lessons learned from the hedgehog and Wnt signal transduction pathways. Annual review of pharmacology and toxicology. 2011; 51: 289-310.

52. Apperley JF. Chronic myeloid leukaemia. Lancet. 2015; 385:1447-1459.

53. Regmi SC, Park SY, Kim SJ, Banskota S, Shah S, Kim DH, Kim JA. The Anti-Tumor Activity of Succinyl Macrolactin A Is Mediated through the beta-Catenin Destruction Complex via the Suppression of Tankyrase and PI3K/Akt. PloS one. 2015; 10:e141753.

54. Meng F, Li H, Shi H, Yang Q, Zhang F, Yang Y, Kang L, Zhen T, Dai S, Dong Y, Han A. MACC1 downregulation inhibits proliferation and tumourigenicity of nasopharyngeal carcinoma cells through Akt/beta-catenin signaling pathway. PloS one. 2013; 8:e60821.

55. Cross DA, Alessi DR, Cohen P, Andjelkovich M, Hemmings BA. Inhibition of glycogen synthase kinase-3 by insulin mediated by protein kinase B. Nature. 1995; 378:785-789.

56. Ishibe S, Haydu JE, Togawa A, Marlier A, Cantley LG. Cell confluence regulates hepatocyte growth factor-stimulated cell morphogenesis in a beta-catenin-dependent manner. Molecular and cellular biology. 2006; 26:9232-9243.

57. Voskas D, Ling LS, Woodgett JR. Does GSK-3 provide a shortcut for PI3K activation of Wnt signalling? F1000 biology reports. 2010; 2:82.

58. Cyster JG. Chemokines and cell migration in secondary lymphoid organs. Science (New York, NY). 1999; 286:2098-2102.

59. Muller G, Hopken UE, Stein H, Lipp M. Systemic immunoregulatory and pathogenic functions of homeostatic chemokine receptors. Journal of leukocyte biology. 2002; 72:1-8.

60. Zhang C, Cui GH, Liu F, Wu QL, Chen Y. Inhibitory effect of triptolide on lymph node metastasis in patients with nonHodgkin lymphoma by regulating SDF-1/CXCR4 axis in vitro. Acta pharmacologica Sinica. 2006; 27:1438-1446.

61. Salgia R, Quackenbush E, Lin J, Souchkova N, Sattler M, Ewaniuk DS, Klucher KM, Daley GQ, Kraeft SK, Sackstein R, Alyea EP, von Andrian UH, Chen LB, et al. The BCR/ $\mathrm{ABL}$ oncogene alters the chemotactic response to stromalderived factor-1alpha. Blood. 1999; 94:4233-4246.

62. Kim $\mathrm{CH}$, Broxmeyer HE. In vitro behavior of hematopoietic progenitor cells under the influence of chemoattractants: stromal cell-derived factor-1, steel factor, and the bone marrow environment. Blood. 1998; 91:100-110.

63. Elrick LJ, Jorgensen HG, Mountford JC, Holyoake TL. Punish the parent not the progeny. Blood. 2005; 105:18621866.

64. Sison EA, Brown P. The bone marrow microenvironment and leukemia: biology and therapeutic targeting. Expert review of hematology. 2011; 4:271-283.

65. Uy GL, Rettig MP, Motabi IH, McFarland K, Trinkaus KM, Hladnik LM, Kulkarni S, Abboud CN, Cashen AF, StockerlGoldstein KE, Vij R, Westervelt P, DiPersio JF. A phase 1/2 study of chemosensitization with the CXCR4 antagonist plerixafor in relapsed or refractory acute myeloid leukemia. Blood. 2012; 119:3917-3924.

66. Hideshima T, Bergsagel PL, Kuehl WM, Anderson KC. Advances in biology of multiple myeloma: clinical applications. Blood. 2004; 104:607-618.

67. Garrido SM, Appelbaum FR, Willman CL, Banker DE. Acute myeloid leukemia cells are protected from spontaneous and drug-induced apoptosis by direct contact with a human bone marrow stromal cell line (HS-5). Experimental hematology. 2001; 29:448-457.

68. Burger JA, Kipps TJ. CXCR4: a key receptor in the crosstalk between tumor cells and their microenvironment. Blood. 2006; 107:1761-1767.

69. Kong X, Liu Y, Ye R, Zhu B, Zhu Y, Liu X, Hu C, Luo $\mathrm{H}$, Zhang Y, Ding Y, Jin Y. GSK3beta is a checkpoint for TNF-alpha-mediated impaired osteogenic 
differentiation of mesenchymal stem cells in inflammatory microenvironments. Biochimica et biophysica acta. 2013; 1830:5119-5129.

70. Matsuda T, Zhai P, Maejima Y, Hong C, Gao S, Tian B, Goto K, Takagi H, Tamamori-Adachi M, Kitajima S, Sadoshima J. Distinct roles of GSK-3alpha and GSK3beta phosphorylation in the heart under pressure overload. Proceedings of the National Academy of Sciences of the United States of America. 2008; 105:20900-20905.

71. Kim YS, Noh MY, Kim JY, Yu HJ, Kim KS, Kim SH, Koh SH. Direct GSK-3beta inhibition enhances mesenchymal stromal cell migration by increasing expression of beta-PIX, CXCR4. Molecular neurobiology. 2013; 47:811-820.

72. Liu J, Han G, Liu H, Qin C. Suppression of cholangiocarcinoma cell growth by human umbilical cord mesenchymal stem cells: a possible role of Wnt and Akt signaling. PloS one. 2013; 8:e62844.
73. Jin L, Tabe Y, Konoplev S, Xu Y, Leysath CE, Lu H, Kimura S, Ohsaka A, Rios MB, Calvert L, Kantarjian H, Andreeff M, Konopleva M. CXCR4 up-regulation by imatinib induces chronic myelogenous leukemia (CML) cell migration to bone marrow stroma and promotes survival of quiescent CML cells. Molecular cancer therapeutics. 2008; 7:48-58.

74. Gregory MA, Phang TL, Neviani P, Alvarez-Calderon F, Eide CA, O’Hare T, Zaberezhnyy V, Williams RT, Druker BJ, Perrotti D, Degregori J. Wnt/Ca2+/NFAT signaling maintains survival of $\mathrm{Ph}+$ leukemia cells upon inhibition of Bcr-Abl. Cancer cell. 2010; 18:74-87.

75. Zhang M, Pan Y, Dorfman RG, Chen Z, Liu F, Zhou Q, Huang S, Zhang J, Yang D, Liu J. AR-42 induces apoptosis in human hepatocellular carcinoma cells via HDAC5 inhibition. Oncotarget. 2016; 7:22285-22294. http://doi. org/10.18632/oncotarget.8077. 